\title{
RESENHA \\ A MEDIDA DE SEGURANÇA DO PONTO DE VISTA DE UM GESTOR DO MINISTÉRIO DA SAÚDE
}

Gonçalves, Renata (2008) A medida de segurança: elementos para interpretação da contenção por tempo indeterminado dos loucos infratores no Brasil. Dissertação de Mestrado. Programa de Pós-Graduação em Antropologia Social. Departamento de Antropologia. Instituto de Ciências Sociais. UNB. 111 pgs.

Martinho Braga Batista e Silva Consultor da Área Técnica de Saúde no Sistema Penitenciário - Ministério da Saúde

A dissertação da psicóloga Renata Weber Gonçalves - da Coordenação Nacional de Saúde Mental da Secretaria de Atenção em Saúde, no Ministério da Saúde - é sobre a sentença dada por juízes a pessoas consideradas inimputáveis: a medida de segurança.

A autora sustenta a necessidade de transitar do paradigma da defesa social para o dos direitos humanos, de modo que cada vez mais pessoas portadoras de transtorno mental que cometem infrações não tenham como destino o confinamento sem data para terminar nos Hospitais de Custódia e Tratamento Psiquiátrico (HCTP).

Sustenta essa necessidade com base em uma rigorosa revisão bibliográfica sobre o tema, no depoimento das próprias pessoas em medida de segurança e na análise de um caso midiático recente, conhecido como “Maníaco da Cantareira”. Entre a tutela do
Estado e aquela da Família, o discurso dos internos revela os dilemas desse trânsito entre paradigmas.

$\mathrm{O}$ instituto jurídico da medida de segurança instaura-se partindo do seguinte pressuposto: a inimputabilidade, que não concede às pessoas portadoras de transtorno mental a possibilidade responder juridicamente pelos seus atos. Seus conceitos chaves são a periculosidade, a prevenção e a adaptação / tratamento. A perícia médica é seu operador fundamental.

Seu estudo permite supor que recortes de raça e classe social contribuem, junto com o diagnóstico de transtorno mental, para colocar as pessoas em medida de segurança nessa situação parecida com uma prisão perpétua.

Além disso, dado o conjunto de leis relativas ao HCTP reunidas, organizadas e comentadas, essa dissertação de mestrado deve ser consultada por todos os envolvidos no atendimento a pessoas em medida de segurança. 